\title{
PENILAIAN DIRI DALAM KETERAMPILAN BERBICARA BAHASA JERMAN SEBAGAI WUJUD PENILAIAN DALAM PENDIDIKAN ABAD XXI
}

\author{
Winarti ${ }^{1}$, Rosyidah ${ }^{2}$ \\ Universitas Negeri Malang \\ Malang, Indonesia \\ e-mail: winarti.1602416@students.um.ac.id ${ }^{1}$,rosyidah.fs@um.ac.id ${ }^{2}$

\begin{tabular}{|l|l|l|}
\hline (C) (1) & \multicolumn{3}{|c|}{$\begin{array}{l}\text { This is an open-access article under the } \text { CC BY-SA license. } \\
\text { Copyright } \odot 2020 \text { by Author. Published by Universitas Pendidikan Ganesha. }\end{array}$} \\
\hline Received : November, 2020 & Accepted : December, 2020 & Published : December, 2020 \\
\hline
\end{tabular}

\begin{abstract}
Tulisan ini adalah hasil kajian kepustakaan yang bertujuan untuk mengetahui dan mengkonseptualisasikan teknik penilaian diri dalam keterampilan berbicara bahasa Jerman yang relevan dengan keterampilan yang harus dikuasai dalam menghadapi tantangan pendidikan abad XXI. Untuk merumuskan hasil kajian kepustakaan, lebih dari tiga artikel yang relevan dipelajari, direview, dibandingkan, dan disajikan oleh penulis untuk mencapai tujuan penelitian ini. Hasil kajian kepustakaan menunjukkan bahwa teknik penilaian diri adalah sebuah teknik penilaian yang efektif dan cocok untuk digunakan dalam perkembangan pendidikan abad XXI, karena teknik penilaian tersebut mampu mengembangkan keterampilan berpikir kritis mahasiswa. Selain itu, teknik penilaian diri juga dapat mengidentifikan kekuatan dan kelemahan mahasiswa, sehingga mahasiswa dapat berinstrospeksi diri. Dengan demikian, mahasiswa dapat lebih menyadari kelebihan yang ada dalam dirinya serta mampu memperbaiki kelemahan yang dimilikinya secara kritis.
\end{abstract}

Kata-kata kunci: Penilaian diri, pendidikan abad XXI, keterampilan berbicara bahasa Jerman

\begin{abstract}
This writing based on the result of literature review that aimed to figure out and conceptualize self-assessment technique in German speaking skill that is relevant with skills which have to be mastered in facing the challenge of education in $21^{\text {st }}$ century. To formulate the results of the literature review, more than three relevant articles were studied, reviewed, compared, and presented by the author in order to obtain the aim of this research. The result of the literature review shows that self-assessment is effective and suitable to be used in in $21^{\text {st }}$ century learning, because it is can improve student's critical thinking. Furthermore, selfassessment technique also the students can identify their strength and weakness, so that students can introspect themselves. Therefore, students can be more aware of their own strengths and be able to critically improve their weaknesses.
\end{abstract}

Keywords: Self-assessment, $21^{\text {st }}$ century learning, German speaking skill 


\section{PRASI JURnal Bahasa, SENI, DAN PENGAJARANNYA \\ VOL. 15 | No. 02 | Desember 2020 \\ ISSN: Print 1693-6124 - Online 2614-1116}

Undiksha | DOI: http://dx.doi.org/10.23887/prasi.v15i02.29844 |https://ejournal.undiksha.ac.id/index.php/PRASI

\section{PENDAHULUAN}

Dalam dunia pendidikan perguruan tinggi, penilaian selalu dikaitkan dengan dosen dan mahasiswa. Adanya perkembangan dalam dunia pendidikan menyebabkan perlunya adanya inovasi dalam proses penilaian hasil belajar mahasiswa. Artinya, dosen tidak hanya bisa mengandalkan penilaian dengan menggunakan tes, ulangan, dan tanya jawab saja, melainkan juga dibutuhkan teknik penilaian yang lain yang bisa membantu dosen dalam menilai mahasiswa secara efektif dan efisien sesuai dengan perkembangan dalam dunia pendidikan yang terjadi saat ini.

Dalam kaitannya dengan perkembangan pendidikan, saat ini dunia berada di era revolusi industri 4.0. Hal ini membuat seluruh sumber daya manusia (SDM), khususnya mahasiswa, harus menyiapkan dirinya agar mampu bersaing dalam skala global (Lase, 2019). Lembaga pendidikan memiliki peran yang cukup vital untuk mencetak SDM yang unggul dan berkualitas. Menurut Hasibuan dan Prastowo (2019), lembaga pendidikan adalah salah satu lembaga yang mampu mengembangkan potensi seseorang agar menjadi SDM yang berkualitas serta mampu mencetak output yang unggul.

Kunci keberhasilan dalam menghadapi persaingan di era industri 4.0 adalah SDM yang unggul dan berkualitas. Menurut Zubaidah (2016), lembaga pendidikan, khususnya perguruan tinggi dan universitas, dianggap sebagai salah satu lembaga yang dapat mempersiapkan mahasiswanya untuk menguasai berbagai ketrampilan sehingga menjadikannya lulusan unggul dan berkualitas. Oleh karena itu, untuk menghadapi tantangan di era revolusi industri 4.0, maka mahasiswa diharapkan memiliki berbagai keterampilan.

Pendidikan 4.0 merupakan era pendidikan yang selalu berkaitan dengan pendidikan di abad XXI (Redhana, 2019). Menurut Sajidan, Baedhowi, Triyanto, Totalia, dan Masykuri (2018), untuk menghadapi pendidikan abad XXI diperlukan beberapa keterampilan, seperti keterampilan berpikir secara kritis (critical thinking) dan keterampilan komunikasi. Berkaitan dengan hal tersebut, Yamin (2012) menyatakan bahwa keterampilan berpikir secara kritis sangat diperlukan dalam proses pembelajaran di era pendidikan abad XXI. Pemecahan masalah secara kritis oleh mahasiswa mampu memberikan pembelajaran yang bermakna bagi dirinya karena akan diingat dalam jangka waktu yang relatif panjang.

Berdasarkan hasil penelitian Widihastuti (2015) tentang model penilaian untuk pembelajaran abad XXI, model penilaian assessment for learning (AFL) adalah salah satu model pembelajaran yang dianggap dapat mengembangkan kemampuan berpikir kritis dan kreatif serta menumbuhkan karakter positif dalam diri mahasiswa. Melibatkan mahasiswa dalam setiap kegiatan penilaian merupakan salah satu karakteristik AFL. Perwujudan kegiatan penilaian tersebut adalah self-assessment (SA).

Secara garis besar, $S A$ merupakan teknik penilaian yang membuat mahasiswa terlibat untuk menilai dirinya sendiri. Hal ini sesuai dengan pendapat Arikunto (2015) yang menyatakan bahwa penilaian diri merupakan teknik penilaian oleh mahasiswa untuk menilai status, proses, dan ketercapaian materi yang mereka pelajari dalam mata kuliah yang didasarkan pada standar tertentu. Sementara itu, menurut Wijayanti (2017), penilaian diri merupakan teknik penilaian yang membuat mahasiswa memiliki kesempatan untuk bertanggung jawab atas capaian belajar mereka. Hal yang berbeda diungkapkan oleh Mirici (2015): "Self-assessment is one of the key practices to develop 
self-awareness in the educational process". Artinya, penilaian diri adalah salah satu praktik utama untuk mengembangkan kesadaran diri dalam proses pendidikan.

Melalui penilaian diri, mahasiswa dapat memahami kekuatan dan kelemahannya sendiri, sehingga pembelajaran menjadi lebih efektif (BaŞak, 2019). Klenowski (dalam Adliswil, 2018) memperkuat pernyataan tersebut, yang mendefinisikan penilaian diri sebagai kegiatan yang mengevaluasi atau menilai kinerja mahasiswa dan mengidentifikasi kekuatan dan kelemahannya, dengan tujuan untuk meningkatkan kegiatan belajar yang dilakukan oleh mahasiswa.

Menurut Jihad dan Haris (2012), dosen harus membuat rubrik penilaian yang sesuai dengan aspek yang akan dinilai sebelum mahasiswa melakukan penilaian diri. Selanjutnya, dosen juga harus merumuskan jenis penilaian yang akan digunakan, pedoman penskoran, dan skala penilaiannya. Penilaian yang digunakan dapat berupa pedoman, penskoran, daftar tanda cek, atau skala penilaian. Dengan demikian, mahasiswa dapat menilai diri sesuai dengan rubrik penilaian yang telah disediakan dalam lembar penilaian.

Perlu diketahui bahwa selain berpikir kritis, keterampilan komunikasi juga menjadi kunci dalam menghadapi pendidikan abad XXI. Menurut East (dalam Sajidan, Baedhowi, Triyanto, Totalia, dan Masykuri, 2018), komunikasi dapat membantu mahasiswa mengungkapkan pikiran dan pemikirannya secara verbal, tertulis dan non verbal, dengan tujuan agar audiens dapat menerima informasi secara tepat dan efektif. Berdasarkan pernyataan tersebut, dapat dikatakan bahwa keterampilan komunikasi dapat dicapai melalui keterampilan berbicara.

Keterampilan berbicara merupakan salah satu aspek keterampilan penting dalam bidang kebahasaan, sehingga membutuhkan perhatian dosen secara menyeluruh (Ulfiyani, 2016). Bahkan, menurut Lindawati dan Sengkey (2017), perkembangan keterampilan berbahasa di era globalisasi. Pendidikan abad XXI menuntut semua golongan masyaraat, khususnya mahasiswa, untuk dapat berkomunikasi menggunakan bahasa internasional, misalnya bahasa Inggris. Namun, pada kenyataannya masih banyak bahasa internasional lain yang dapat dipelajari di SMA bahkan universitas, misalnya bahasa Jerman, bahasa Mandarin, bahasa Jepang, dan lain sebagainya.

Dalam kaitannya dengan keterampilan berbicara menggunakan bahasa internasional, Harahap (2017) menjelaskan bahwa kemampuan berkomunikasi dengan bahasa asing merupakan kemampuan individu untuk mengekspresikan, menyatakan, serta menyampaikan pikiran, gagasan, dan perasaan kepada orang lain menggunakan kalimatkalimat dalam bahasa asing. Sementara itu, menurut Gemeinsamer europäischer Refernzrahmen (GER), keterampilan berbicara dalam bahasa Jerman dibedakan ke dalam dua kategori, yaitu keterampilan berbicara berdasarkan konteks, misalnya sebuah monolog atau sebuah pidato di depan umum dan keterampilan berbicara untuk melakukan sebuah komunikasi (Burg, 2013). Berdasarkan pendapat di atas, dapat disimpulkan bahwa keterampilan berbicara dalam bahasa Jerman adalah kemampuan seseorang dalam menggunakan bahasa Jerman untuk berbicara sesuai konteks dan berkomunikasi dengan orang lain.

Senada dengan pendapat Jihad dan Haris (2012), untuk menilai kemampuan berbicara bahasa Jerman pada mahasiswa, dibutuhkan kriteria penilaian yang sesuai dengan pedoman penilaian dalam GER, seperti Spektrum, Korrektheit, Flüssigkeit, Interaktion, dan Kohärenz (Trim, North, Coste, dan Sheils, 2001). Lima aspek penilaian 


\section{PRASI JURnal Bahasa, SENI, DAN PENGAJARANNYA \\ VOL. 15 | No. 02 | Desember 2020 \\ ISSN: Print 1693-6124 - Online 2614-1116}

Undiksha| DOI: http://dx.doi.org/10.23887/prasi.v15i02.29844 |https://ejournal.undiksha.ac.id/index.php/PRASI

di atas jika diterjemahkan ke dalam bahasa Indonesia adalah cakupan, ketepatan, kelancaran, interaksi, dan koherensi bahasa Jerman.

Berdasarkan hasil sebuah penelitian tentang penilaian keterampilan berbicara dalam sebuah video oleh yayasan ilmu pengetahuan Swiss dalam Trim, North, Coste, dan Sheils (2001), ada lima penjelasan secara rinci terkait lima aspek penilaian keterampilan berbicara bahasa Jerman. Pertama, cakupan merujuk pada cakupan dalam kemampuan ilmu linguistik yang meliputi ilmu leksikal, gramatikal, semantik, dan fonologi dalam bahasa Jerman. Kedua, ketepatan dalam konteks ini adalah tepat atau tidaknya penggunaan semua elemen ilmu linguistik di atas, terutama penggunaan gramatika dalam bahasa Jerman. Ketiga, kelancaran adalah kemampuan mahasiswa untuk mengartikulasikan kosakata dalam bahasa Jerman, kemampuan mahasiswa untuk terus berbicara, dan kemampuan mahasiswa untuk mengatasi kesulitan yang dialaminya ketika berkomunikasi. Keempat, interaksi meliputi interaksi antara dua orang atau lebih dan kerja sama mereka dalam berkomunikasi. Kelima, koherensi bahasa Jerman adalah logis atau tidaknya kalimat bahasa Jerman yang digunakan, misalnya penggunaan konjungsi yang sesuai dan masuk akal.

Berdasarkan uraian di atas, dapat disimpulkan bahwa self assessment kemampuan berbicara bahasa Jerman merupakan teknik atau metode penilaian yang memungkinkan mahasiswa mempraktikkan kemampuan berpikir kritis dan keterampilan berkomunikasi agar mahasiswa dapat menguasai keterampilan berbicara sesuai kriteria penilaian tertentu. Penguasaan aspek berbicara bahasa Jerman meliputi pemahaman linguistik, penggunaan kosakata dalam berbicara, kemampuan untuk bekerja sama dalam komunikasi, dan keterampilan bahasa Jerman yang logis dan tepat.

Berdasarkan semua uraian di atas, dalam tulisan ini dijelaskan pentingnya teknik penilaian diri yang dapat dijadikan solusi oleh dosen untuk mengembangkan keterampilan berpikir kritis mahasiswa sebagai alat untuk mengetahui kemampuan dan kelemahan mereka dalam pembelajaran bahasa Jerman, khususnya dalam penguasaan aspek berbicara mahasiswa di era pendidikan abad XXI. Guna mendukung keakuratan tulisan ini, penulis menyajikan beberapa teori yang relevan terkait penilaian diri untuk dibahas secara mendalam.

\section{PEMBAHASAN}

Dalam merumuskan hasil kajian pustaka, penulis memilih lebih dari tiga artikel yang relevan dengan topik tulisan ini untuk dipelajari, direview, dibandingkan, dan disajikan hasilnya pada bagian inti. Artikel-artikel tersebut merupakan artikel hasil sebuah penelitian yang telah diterbitkan dari beberapa jurnal: jurnal realita, jurnal evaluasi dan pendidikan, dan jurnal teknologi pendidikan di Turki. Dengan demikian, penulis dapat menyajikan hasil kajian tersebut dalam berbagai uraian penjelasan berikut ini.

\section{Penilaian Pendidikan Abad XXI}

Kurikulum, proses pembelajaran dan penilaian adalah tiga bagian penting dalam pembelajaran. Ketiga komponen tersebut saling terkait. Adanya pendidikan abad XXI berdampak pada proses pembelajaran dan penilaian sehingga muncul juga istilah pembelajaran abad XXI dan penilaian abad XXI. 
Pelaksanaan pembelajaran revolusi industri 4.0 tidak terlepas dari penilaian abad XXI. Hal tersebut diungkapkan oleh Winaryati (2018) melalui bagan berikut ini.

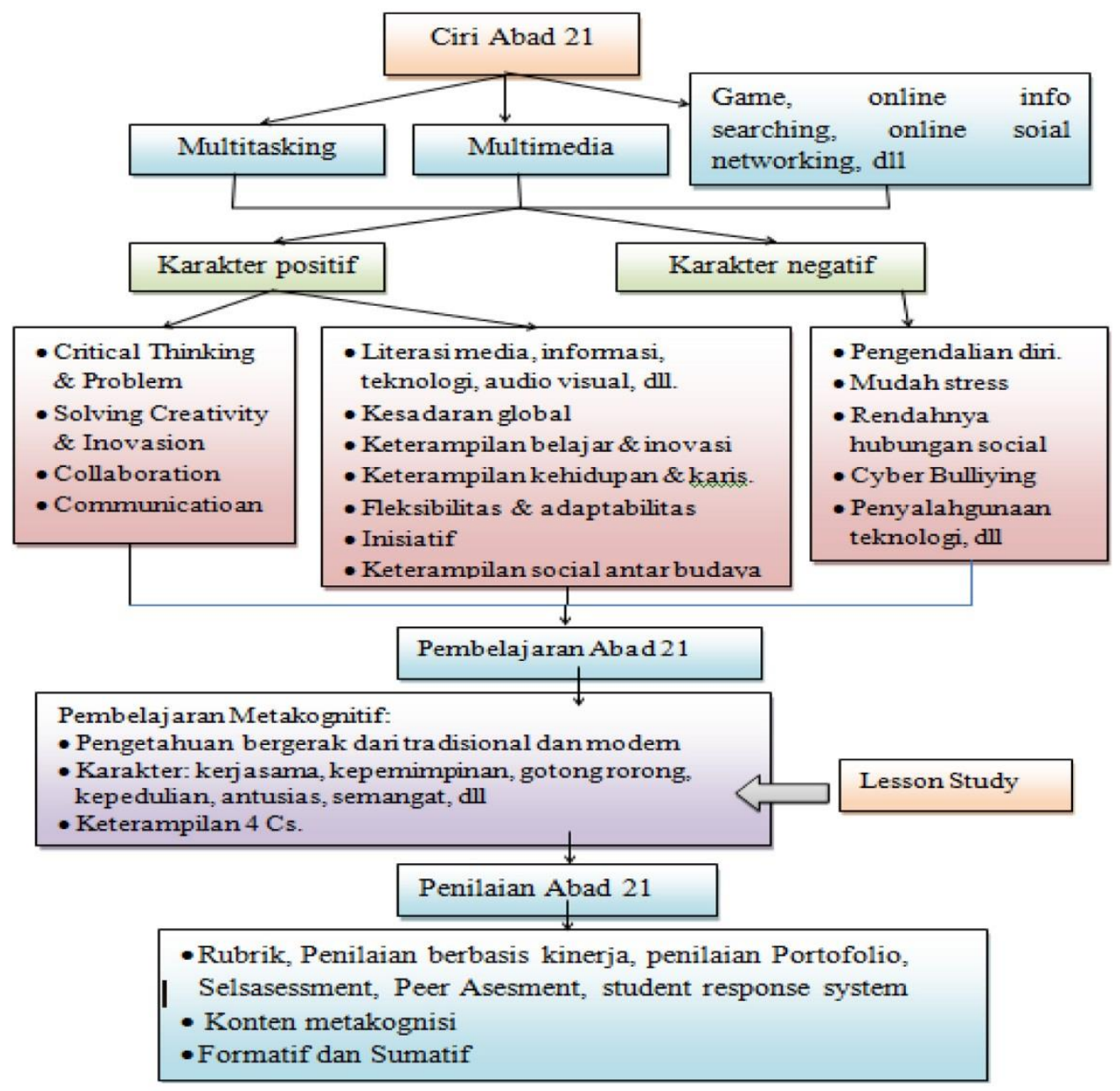

Gambar 1 alur penilaian abad XXI (Sumber: Winaryati, 2018)

Melalui bagan di atas, Winaryati (2018) menjelaskan bahwa pembelajaran 4.0 pada era revolusi industri dan evaluasi pendidikan abad XXI merupakan dua komponen yang tidak dapat dipisahkan. Selain itu, pendidikan abad XXI mempunyai ciri-ciri yang paling mencolok, seperti multitasking, multimedia, game, online info searching, dll. Menurutnya, ciri-ciri tersebut menghasilkan karakter positif dan negatif dalam pembelajaran. Contoh karakter positif yang dihasilkan adalah critical thinking (berpikir kritis) dan communication (komunikasi).

Sejalan dengan pandangan di atas, Sajidan, Baedhowi, Triyanto, Totalia dan Masykuri (2018) menekankan bahwa keterampilan utama untuk menghadapi tantangan pendidikan abad ke-21 adalah keterampilan berpikir kritis dan keterampilan komunikasi. Berkaitan dengan keterampilan berpikir kritis, Widihastuti (2015) mengemukakan bahwa asesmen dengan membiarkan mahasiswa menilai diri sendiri merupakan salah satu jenis asesmen yang dapat mengembangkan keterampilan berpikir kritis pada diri mahasiswa, 
karena jika mereka memiliki keterampilan berpikir tingkat tinggi maka mereka dapat menjadi kritis dan kreatif.

Berkaitan dengan kemampuan berpikir tingkat tinggi, Widihastuti (2015) juga menjelaskan bahwa sistem penilaian yang dapat membiasakan, melatih, dan mengembangkan kemampuan berpikir tingkat tinggi adalah sistem penilaian yang terintegrasi dalam pembelajaran atau biasa disebut dengan Assesment for learning ( $A F L$ ). Dalam penerapan $A F L$, dosen dapat menggunakan beberapa teknik penilaian untuk menilai mahasiswa, salah satunya adalah self assessment atau penilaian diri.

\section{Konsep Self-Assessment (Penilaian Diri)}

Secara umum, penilaian diri merupakan teknik penilaian oleh mahasiswa untuk menilai status, proses, dan ketercapaian materi yang mereka pelajari dalam mata kuliah yang didasarkan pada standar tertentu. Pendapat lain diungkapkan oleh Fauziya dan Suhara (2015) yang menjelaskan bahwa penilaian diri adalah sebuah teknik penilaian yang efektif dan menyenangkan yang dapat dilakukan oleh mahasiswa untuk mengetahui potensi yang ada dalam dirinya serta dapat meningkatkan keterampilan yang dimilikinya. Tidak hanya itu, penilaian diri juga dapat dijadikan sebagai pelengkap dalam proses penilaian selain melalui tes (ujian), karena menurut mahasiswa penilaian hanya dilakukan oleh dosen sehingga membuat mereka bingung untuk memperbaiki dirinya sendiri.

Definisi yang berbeda mengenai penilaian diri juga dikemukakan oleh Feri, Simadibrata, dan Jusuf (2015) yang berpendapat bahwa penilaian diri adalah suatu aksi yang dilakukan untuk menilai diri sendiri dengan tujuan membuat keputusan untuk langkah selanjutnya. Sementara itu, Arikunto (2015) menegaskan bahwa self-assessment adalah suatu cara penilaian yang dilakukan dengan melibatkan mahasiswa untuk menilai dirinya sendiri sesuai dengan standar yang telah ditentukan dalam suatu mata kuliah tertentu. Selain pendapat-pendapat di atas, ada pula pendapat Mirici (2015) yang menekankan bahwa penilaian diri adalah salah satu praktik utama untuk mengembangkan kesadaran diri dalam proses pendidikan.

Dalam konteks pembelajaran di dalam kelas, penilaian diri berkaitan erat dengan kompetensi afektif, kognitif, dan psikomotorik mahasiswa. Wahyuni (2012) juga menuliskan hal yang sama, yakni penilaian diri dapat digunakan untuk mengukur kemampuan kognitif, emosional, dan psikomotorik. Dalam proses pembelajaran yang berkaitan dengan kemampuan kognitif di kelas, mahasiswa mungkin dituntut untuk menilai penguasaan pengetahuan dan keterampilan berpikirnya karena mereka belajar pada mata pelajaran tertentu sesuai dengan standar atau bahan acuan yang telah disiapkan. Dalam hal kemampuan afektif, mahasiswa dapat diminta untuk menuliskan perasaannya terhadap objek sikap tertentu. Dalam hal kemampuan psikomotorik, mahasiswa dapat diminta untuk mengevaluasi keterampilan yang telah dikuasainya setelah pembelajaran berdasarkan standar atau bahan acuan yang telah disiapkan.

Untuk menyusun lembar penilaian diri, hendaknya dosen mengikuti kriteria sebagai berikut:

1. Pertanyaan berisi seputar pendapat, tanggapan dan sikap,

2. kata-kata yang digunakan tidak membuat mahasiswa bingung,

3. pertanyaan harus jelas dan sesuai dengan topik,

4. tidak boleh menggunakan pertanyaan yang mengandung makna ganda, dan

5. pertanyaan harus berlaku bagai semua mahasiswa (Majid, 2015). 
Pusat kurikulum (dalam Arikunto, 2015) menjelaskan bahwa terdapat tiga jenis penilaian diri yang dapat dilakukan oleh mahasiswa dengan arahan dari dosen, yaitu penilaian langsung dan spesifik, penilaian tidak langsung dan holistik, dan penilaian sosio-afektif. Berikut ini adalah penjelasan lebih rinci tentang ketiga hal tersebut.

1. Penilaian langsung dan spesifik adalah penilaian yang dilakukan langsung oleh mahasiswa setelah menyelesaikan suatu kegiatan (seperti ulangan harian atau menyelesaikan tugas kelas),

2. Penilaian tidak langsung dan holistik adalah penilaian yang tidak dilakukan secara langsung saat menyelesaikan suatu kegiatan (misalnya, tugas yang harus diselesaikan di rumah),

3. penilaian sosio-afektif adalah ketelitian atau ketelitian, kerapian, kebersihan dan faktor afektif lainnya.

Adapun langkah-langkah untuk melakukan self-assesment menurut Jihad dan Haris. (2012) adalah sebagai berikut:

1. Menentukan kemampuan atau aspek kemampuan yang akan dinilai,

2. Tentukan kriteria evaluasi yang akan digunakan,

3. Menentukan format evaluasi, dapat berupa kriteria penilaian, daftar tanda centang atau skala nilai,

4. Meminta mahasiswa untuk melakukan penilaian diri,

5. Mengambil sampel hasil evaluasi secara acak untuk mendorong mahasiswa agar selalu melakukan evaluasi diri dengan hati-hati dan obyektif; dan

6. Memberikan saran kepada mahasiswa berdasarkan evaluasi hasil penelitian yang dipilih secara acak.

Penggunaan metode penilaian diri akan berdampak positif dan negatif terhadap perkembangan kepribadian peserta didik, karena cara penilaian diri memiliki kelebihan dan kekurangan. Lestari (2016) menyebutkan bahwa ada enam kelebihan penggunaan teknik penilaian diri. Enam kelebihan teknik penilaian diri tersebut adalah sebagai berikut.

1. Penilaian diri dapat digunakan untuk mengukur semua aspek kemampuan kognitif.

2. Penilaian diri dapat digunakan untuk mengukur semua aspek kemampuan emosional (afektif).

3. Penilaian diri dapat digunakan untuk mengukur semua aspek kemampuan psikomotorik.

4. Penilaian diri dapat meningkatkan motivasi belajar mahasiswa.

5. Penilaian diri dapat membantu mahasiswa terbiasa dengan kejujuran.

6. Penilaian diri dapat membangun kecerdasan emosional dan kemampuan peningkatan diri.

Berdasarkan pada pendapat di atas, dapat dikatakan bahwa teknik penilaian diri dapat membantu mahasiswa menyadari kekuatan dan kelemahan masing-masing serta dapat membantu mereka memperbaiki keterampilan berbicara yang dimilikinya. Setelah mahasiswa menyadari kekuatan dan kelemahannya, mereka akan mendapatkan umpan balik yang dapat memotivasi mereka untuk mengubah gaya belajar mereka menjadi lebih baik, menggunakan waktu belajar yang dimiliki dengan tepat dan efisien, dan lain sebagainya (Wijayanti dan Mundilarto, 2015). Oleh sebab itu, mahasiswa yang mengetahui kekuatan dan kelemahannya dalam proses pembelajaran, khususnya dalam 


\section{PRASI JURnal Bahasa, SENI, DAN PENGaUARANNYA \\ VOL. 15 | No. 02 | Desember 2020 \\ ISSN: Print 1693-6124 - Online 2614-1116}

Undiksha | DOI: http://dx.doi.org/10.23887/prasi.v15i02.29844 |https://ejournal.undiksha.ac.id/index.php/PRASI

keterampilan berbicara bahasa Jerman, dapat meningkatkan kemampuannya dalam berbicara menggunakan bahasa Jerman. Hal ini dikarenakan mereka dapat melakukan introspeksi diri untuk menilai kemampuan yang ada dalam dirinya serta dapat meningkatkan motivasi belajarnya (Trim, North, Coste, dan Sheils, 2001).

Selain memiliki kelebihan, Lestari (2016) menegaskan bahwa penilaian diri juga memiliki tiga kekurangan. Ketiga kekurangan tersebut adalah sebagai berikut.

1. Ada kemungkinan mahasiswa melakukan kesalahan dalam penilaian, karena mereka belum terbiasa dan terlatih.

2. Ada kemungkinan mahasiswa sangat subjektif dalam melakukan penilaian, karena mereka ingin mendapat nilai yang bagus.

3. Membutuhkan waktu dan kesabaran, karena dosen harus membaca dan mengevaluasi satu persatu.

Untuk mengatasi kekurangan dari penggunaan penilaian diri di atas, perlu adanya pengenalan dan pelatihan keterampilan penggunaan teknik penilaian diri sejak dini, agar mahasiswa dapat terlatih melakukan penilaian diri secara obyektif dan jujur (Feri, Simadibrata, dan Jusuf, 2015).

\section{Keterampilan Berbicara Bahasa Jerman}

Manusia membutuhkan bahasa untuk berkomunikasi. Menurut Lestuny (2020), bahasa dapat dikatakan sebagai kunci utama kehidupan manusia di dunia. Tanpa bahasa, kehidupan manusia tidak akan berarti, karena dengan bahasa manusia dapat memberikan dan memperoleh informasi. Dalam konteks ini, Baroya (2018) menjelaskan bahwa keterampilan komunikasi mengacu pada kemampuan menentukan, menggunakan, dan memaksimalkan alat dan cara mahasiswa mengkomunikasikan informasi dengan orang lain. Keterampilan komunikasi mengacu pada kemampuan untuk mengidentifikasi, mengakses, memanfaatkan dan mengoptimalkan alat dan metode yang dikomunikasikan mahasiswa untuk menerima dan menyampaikan informasi kepada orang lain. Oleh karena itu, dapat dikatakan bahwa komunikasi dapat membantu mahasiswa mengungkapkan pikiran dan pemikirannya secara lisan, tertulis dan non verbal, sehingga khalayak dapat menerima informasi secara tepat dan efektif (East dalam Sajidan, Baedhowi, Triyanto, Totalia dan Masykuri, 2018). Dari pernyataan di atas, dapat disimpulkan bahwa ada tiga cara komunikasi yaitu komunikasi lisan, tertulis dan non verbal.

Agar mahasiswa yang sedang belajar bahasa Jerman dapat berkomunikasi dalam bahasa Jerman secara lisan dan komunikatif, mereka dituntut untuk menguasai ketarampilan berbicara bahasa Jerman (Sprechfertigkeit). Abidin (Lestuny, 2020) mengemukakan bahwa kemampuan ekspresi lisan (berbicara) merupakan ciri penting dari kemampuan komunikasi mahasiswa. Sementara itu, Harahap (2017) berpendapat bahwa penggunaan bahasa asing adalah kemampuan untuk mengungkapkan, menyatakan dan menyampaikan pikiran, gagasan, dan perasaan kepada orang lain dalam bahasa asing.

Mengenai kemampuan berbicara dalam bahasa internasional, berbicara bahasa Jerman merupakan salah satu dari empat keterampilan yang berperan penting dalam pembelajaran bahasa Jerman, karena melalui kegiatan berbicara, mahasiswa dapat menyampaikan informasi dan pengetahuan tentang berbagai bidang ilmu. Empat keterampilan berbahasa dalam pembelajaran bahasa Jerman meliputi mendengar (Hören), berbicara (Sprechen), membaca (Lesen), dan menulis (Schreiben). 
Pada umumnya, untuk menilai empat keterampilan berbahasa di atas, dosen diharuskan menggunakan acuan penilaian dalam Gemeinsamer europäischer Referenzrahmen (GER), termasuk untuk menilai keterampilan berbicara. Hal tersebut menunjukkan bahwa kriteria dan aspek untuk menilai keterampilan berbicara juga diatur sesuai dengan GER. GER telah membagi aspek penilaian penting dalam keterampilan berbicara bahasa Jerman menjadi lima kategori yang meliputi (1) Cakupan dalam ilmu linguistik, (2) Ketepatan, (3) Kelancaran, (4) Interaksi, dan (5) Koherensi. Uraian terkait lima aspek penilaian keterampilan berbicara bahasa Jerman disajikan berikut ini.

\section{Penggunaan Penilaian Diri oleh Mahasiswa di Indonesia dan Luar Negeri}

Penggunaan teknik penilaian diri telah dilakukan oleh beberapa siswa dan mahasiswa di Indonesia dan luar negeri. Pengaruh dari penggunaan teknik penilaian tersebut juga sangat berdampak besar terhadap perkembangan kepribadian mahasiswa itu sendiri.

Berdasarkan hasil penelitian Wijayanti (2017) tentang pembentukan karakter siswa melalui teknik penilaian diri, menjelaskan bahwa implementasi penilaian diri dilakukan melalui lembar penilaian diri yang berisi kriteria penilaian yang telah ditentukan berdasarkan acuan dalam kompetensi inti dan kompetensi dasar dalam suatu mata pelajaran tertentu. Dalam lembar penilaian tersebut terdapat beberapa kriteria penilaian yang sesuai dengan aspek yang akan dinilai. Dapat berupa aspek kognitif, psikomotorik, dan afektif. Dalam hal ini, lembar penilaian diri dibuat sesuai dengan aspek penilaian sikap, sehingga dapat diketahui karakter dan kepribadian positif siswa. Pada tabel 1 di bawah ini adalah contoh lembar penilaian diri dalam aspek penilaian sikap.

Tabel 1 Lembar penilaian Diri Aspek Sikap

Sumber: Wijayanti (2017)

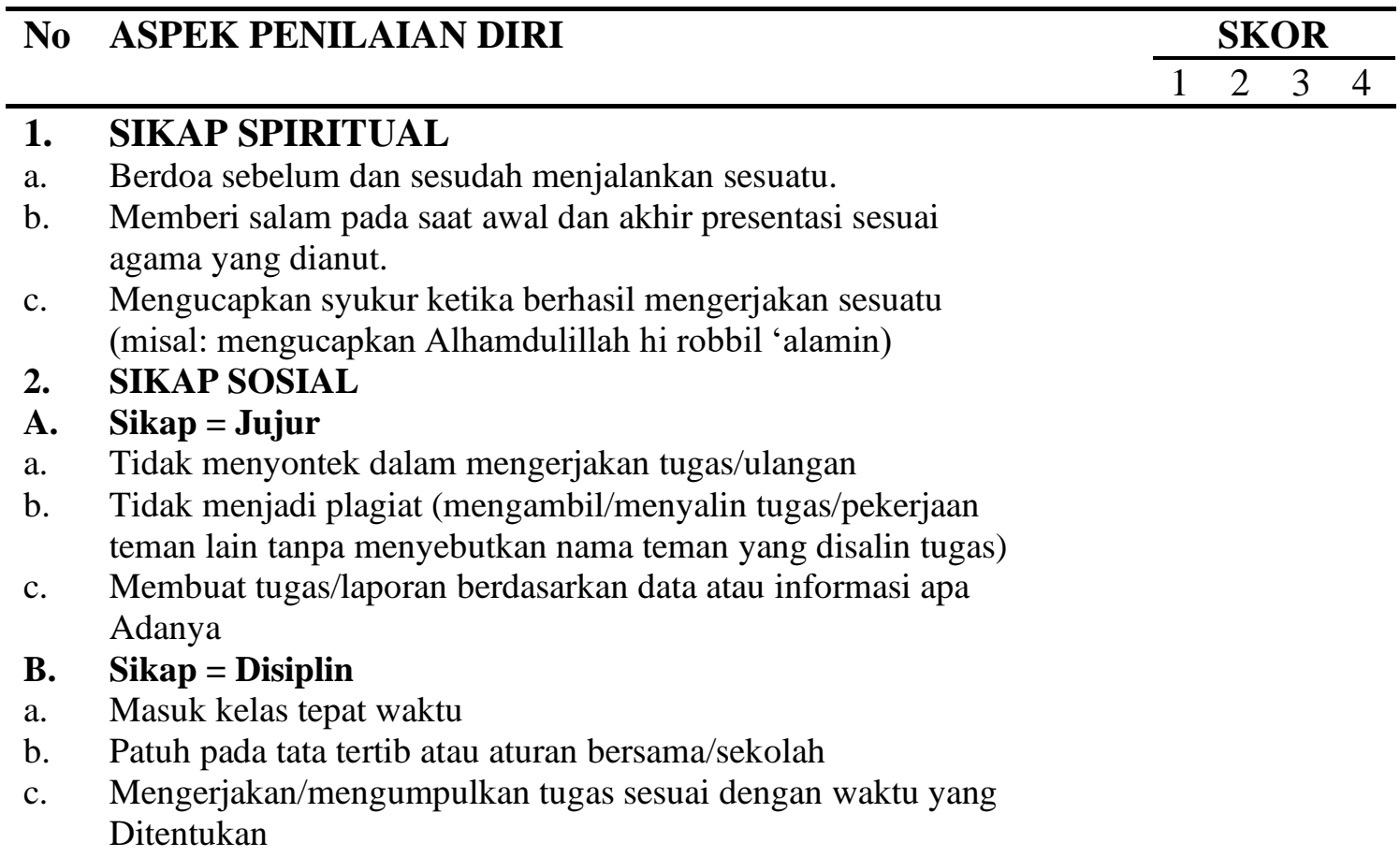




\section{PRASI JuRnal bahasa, SENI, dAN PEngalarannya \\ VOL. 15 | No. 02 | Desember 2020 \\ ISSN: Print 1693-6124 - Online 2614-1116}

Undiksha| DOI: http://dx.doi.org/10.23887/prasi.v15i02.29844 |https://ejournal.undiksha.ac.id/index.php/PRASI

C. Sikap = Tanggung Jawab

a. Tidak menyalahkan/menuduh orang lain tanpa bukti yang

Akurat

b. Mengembalikan barang yang dipinjam

c. Menepati janji yang telah diucapkan

D. Sikap $=$ Toleransi

a. Tidak mengganggu teman yang berbeda pendapat

b. Menerima kesepakatan meskipun berbeda dengan pendapatnya

c. Mampu dan mau bekerja sama dengan siapa pun yang

memiliki keberagaman latar belakang pandangan dan

keyakinan

E. $\quad$ Sikap $=$ Gotong Royong

a. Aktif dalam bekerja bakti membersihkan kelas atau sekolah

b. Kesediaan melakukan tugas sesuai kesepakatan

c. Bersedia membantuorang lain tanpamengharap imbalan

F. Sikap = Sopan Santun

a. Menghormati orang lebih tua

b. Tidak berkata kotor, kasar, dan takabur

c. Bersikap 3S ( salam, senyum, sapa)

G. Sikap = Percaya Diri

a. Berpendapat atau melakukan kegiatan tanpa ragu-ragu

b. Mampu membuat keputusan dengan cepat

c. Tidak mudah putus asa

Selain itu, menurut hasil penelitian Mirici (2015) tentang penggunaan alat penilaian diri digital yang disebut dengan EPOSTL dalam pembelajaran bahasa asing, menunjukkan bahwa dengan menggunakan alat tersebut dalam melakukan penilaian diri, mahasiswa yang sedang belajar bahasa Jerman memiliki nilai rata-rata yang lebih tinggi dalam segala aspek daripada mahasiswa yang sedang belajar bahasa Inggris. Hal tersebut membuktikan bahwa penggunaan teknik penilaian diri dalam pembelajaran bahasa Jerman dapat membawa dampak positif bagi mahasiswa yang sedang belajar bahasa Jerman.

\section{Penilaian Diri dalam Keterampilan Berbicara bahasa Jerman sebagai Wujud Penilaian dalam Pendidikan Abad XXI}

Penilaian sangat berperan besar dalam menentukan kesuksesan pendidikan. Pernyataan tersebut diperkuat oleh Jihad dan Haris (2012) yang menjelaskan bahwa penilaian adalah kegiatan yang sangat penting dalam pembelajaran. Hal yang sama juga diungkapkan oleh Darginaviciene (2017) yang menekankan bahwa penilaian dan penilaian diri telah menjadi bagian penting dalam pembelajaran dan pengajaran bahasa asing. Oleh sebab itu, penilaian dalam keterampilan berbicara bahasa Jerman adalah kegiatan penilaian yang penting yang dilakukan untuk mengetahui kemampuan mahasiswa dalam berbicara bahasa Jerman.

Pendidikan di abad XXI menuntut siswa memiliki berbagai keterampilan. Griffin, McGaw dan Care (dalam Zubaidah, 2016) membagi keterampilan abad XXI menjadi empat kategori, yaitu (1) gaya berpikir, meliputi berpikir kritis, pemecahan masalah, inovasi, kreativitas, dan kemampuan mengambil keputusan; (2) gaya kerja, meliputi keterampilan komunikasi, kerjasama dan kerja tim; (3) alat kerja, termasuk kesadaran 
menjadi warga global dan sosial; (4) keterampilan untuk hidup di era modern yang berdasarkan pada literasi informasi, penguasaan teknologi informasi dan komunikasi baru, serta kemampuan belajar dan bekerja melalui jejaring sosial digital. Berdasarkan pendapat di atas, salah satu keterampilan yang dapat dikembangkan melalui kegiatan penilaian adalah keterampilan berpikir secara kritis.

Berkaitan dengan hal tersebut, Widihastuti (2015) berpendapat bahwa penilaian yang dapat mengembangkan keterampilan berpikir kritis mahasiswa adalah penilaian yang dilakukan melalui proses penilaian yang memungkinkan siswa untuk melakukan penilaian diri. Dengan mengacu pada sudut pandang tersebut maka dapat disimpulkan bahwa self assessment merupakan penilaian yang dapat diterapkan pada era pendidikan abad XXI. Melalui self assessment mahasiswa dapat menggali, menemukan dan mengungkapkan kelebihan dan kekurangannya dengan berbagai cara, dapat merespon, memperbaiki kelemahan diri sendiri, serta menambah dan mengembangkan kekuatan diri sendiri (Lestari, 2016).

Griffin, McGaw and Care (Zubaidah, 2016) dan Muhali (2019) menjelaskan bahwa untuk menghadapi tantangan masa kini dan masa depan yang semakin kompleks, khususnya di era pendidikan abad XXI, tidak hanya diperlukan kemampuan berpikir kritis. Tentunya keterampilan komunikasi juga dibutuhkan. Untuk mengembangkan keterampilan komunikasi, mahasiswa harus memiliki kemampuan untuk menguasai keterampilan berbicara, karena keterampilan berbicara merupakan keterampilan komunikasi manusia yang dapat membantu mereka mengungkapkan pikiran, gagasan dan informasi melalui bentuk lisan dan tulisan (Tenri, Asri dan Azizah, 2017) .

Penilaian diri sendiri dalam pembelajaran bahasa, khususnya bahasa Jerman, merupakan teknik penilaian yang digunakan individu untuk menilai kemampuan bahasa Jerman mereka sendiri (Trim, North, Coste dan Sheils, 2001). Untuk melakukan penilaian diri dalam keterampilan berbicara bahasa Jerman dibutuhkan kriteria penilaian yang sesuai dengan acuan penilaian dalam GER.

Berdasarkan pedoman penilaian keterampilan berbicara bahasa Jerman yang telah tercantum dalam GER, kriteria penilaian pada setiap level kebahasaan tidaklah sama, mulai dari level A1 sampai dengan level C2. Setiap aspek penilaian memiliki kriteria penilaian masing-masing, sesuai dengan level kebahasaannya. Berikut adalah rincian penjelasan terkait lima aspek dan kriteria penilaian yang sesuai dengan Trim, North, Coste, dan Sheils (2001).

\section{Spektrum}

Secara global, yang dimaksud dengan Spektrum dalam konteks pembelajaran bahasa mencakup kemampuan mahasiswa terkait ilmu-ilmu linguistik. Menurut penelitian Alek (2018), berbagai linguistik mencakup berbagai ilmu kebahasaan, mulai dari sub disiplin ilmu seperti fonetik, morfologi, gramatika, semantik dan leksikon hingga pengetahuan tentang hubungan antara bahasa, masyarakat dan budaya.

Dalam konteks pembelajaran bahasa Jerman yang berpedoman pada GER, yang dimaksud dengan Spektrum meliputi kemampuan menggunakan struktur kalimat dalam bahasa Jerman, seperti perbendaharaan kata dan frasa terkait informasi tertentu dalam situasi yang konkret. Hal tersebut telah dijelaskan dalam Trim, North, Coste, dan Sheils (2001) yang jika diringkas bahwa kriteria penilaian pada setiap level selalu berbeda dan bertahap. Mulai dari level A1 sampai dengan level C2. Mulai dari kata, frasa, klausa, 


\section{PRASI JURnal Bahasa, SENI, DAN PENGaUARANNYA \\ VOL. 15 | No. 02 | Desember 2020 \\ ISSN: Print 1693-6124 - Online 2614-1116}

Undiksha| DOI: http://dx.doi.org/10.23887/prasi.v15i02.29844 |https://ejournal.undiksha.ac.id/index.php/PRASI

struktur kalimat dasar, Redemittel (ungkapan-ungkapan khusus dalam bahasa Jerman) sampai idiom sehari-hari.

\section{Korrektheit}

Aspek penilaian Korrektheit sama halnya dengan aspek penilaian Genauigkeit. Korrektheit yang dimaksud dalam konteks ini adalah ketepatan dalam penggunaan berbagai macam ilmu linguistik di atas, terutama ketepatan penggunaan gramatika dalam bahasa Jerman (Burg, 2013). Dalam Trim, North, Coste, dan Sheils (2001) dirinci bahwa yang termasuk elemen gramatika dalam bahasa Jerman adalah Artikel (ein, eine, einer, das, die, der), Konjunktionen (konjungsi), misalnya und, aber, obwohl, wenn, Personalpronomen (kata ganti orang) yang meliputi ich, du, er, sie, es, wir, ...; mir, dir, $u s w$, dan lain sebagainya. Semua elemen-elemen tersebut dapat dipelajari dan dikuasai oleh mahasiswa secara bertahap sesuai dengan level kebahasaan yang dimilikinya.

\section{Flüssigkeit}

Aspek penilaian Flüssigkeit secara umum adalah spontanitas dalam mengekspresikan sesuatu sesuai dengan topik dengan cepat serta lancar tanpa ada jeda waktu yang lama. Hal tersebut diperkuat oleh Trim, North, Coste, dan Sheils (2001) yang menjelaskan bahwa: "Flüssigkeit, die Fähigkeit zu artikulieren, weiterzusprechen und damit zurechtzukommen, wenn man an einen toten Punkt gelangt". Artinya, kelancaran adalah kemampuan untuk mengartikulasikan, kemampuan untuk terus berbicara, dan kemampuan untuk mengatasi masalah ketika mengalami kesulitan dalam berkomunikasi. Oleh sebab itu, kriteria penilaian dalam aspek ini sangat berkaitan dengan lama atau tidaknya dan mahasiswa dalam berbicara.

\section{Interaktion}

Aspek penilaian Interaktion secara global mengacu pada cara mahasiswa untuk memulai, mempertahankan, dan mengakhiri sebuah percakapan. GER menjelaskan bahwa Interaktion termasuk salah satu variasi kegiatan bercakap-cakap yang lebih komunikatif. Oleh karena itu, agar percakapan menjadi lebih komunikatif, dibutuhkan sebuah interaksi antar pembicara.

Dengan adanya interaksi antar pembicara, mereka dapat mengajukan pertanyaan satu sama lain dan menjawabnya secara bergantian. Untuk menghindari kesalahpahaman ketika berinteraksi, antar lawan bicara hendaknya harus bekerja sama untuk memastikan bahwa mereka telah mengerti satu sama lain melalui berbagai cara, salah satunya adalah memahami topik yang sedang mereka bicarakan (Trim, North, Coste, dan Sheils, 2001).

5. Kohärenz

Aspek penilaian Kohärenz mengacu pada penggunaan konjungsi sebagai penghubung antar kata atau antar kalimat bahkan antar paragraf secara logis dan gampang dimengerti. Hal yang sama dijelaskan oleh Deutsches Institut für Internationale Pädagogische Forschung (DIPF) (dalam Trim, North, Coste, dan Sheils, 2001) yang menyatakan bahwa koherensi diikuti dengan susunan kalimat yang logis dan meyakinkan serta argumentasi yang koheren dan dapat dipahami.

Pada aspek penilaian ini, mahasiswa dituntut untuk dapat menguasai beberapa konjungsi, mulai dari konjungsi yang sederhana sampai dengan konjungsi yang lebih kompleks. Konjungsi-konjungsi tersebut nantinya dapat digunakan oleh mahasiswa untuk menggabungkan kata, frasa, klausa, kalimat, bahkan paragraf yang lebih logis dan masuk akal (Trim, North, Coste, dan Sheils, 2001). Dengan demikian, mahasiswa dapat memenuhi kriteria penilaian yang terdapat pada aspek penilaian koherensi. 
Berdasarkan pemaparan di atas, dapat ditarik kesimpulan bahwa penilaian diri dalam keterampilan berbicara bahasa Jerman sebagai wujud penilaian dalam pendidikan abad XXI adalah teknik penilaian yang dilakukan dengan melibatkan mahasiswa untuk menilai kemampuan berbicara yang dimilikinya dengan tujuan untuk mengetahui kelemahan dan kekuatan mahasiswa dalam kemampuan berbicara bahasa Jerman secara kritis sesuai dengan aspek penilaian dalam GER. Oleh karena itu, dapat diperjelas kembali bahwa alasan pentingnya penilaian diri dapat dijadikan sebagai wujud penilaian dalam pendidikan abad XXI, karena teknik penilaian tersebut dapat mengembangkan keterampilan berpikir kritis mahasiswa.

\section{SIMPULAN}

Dalam mengevaluasi hasil belajar mahasiswa sangat penting untuk memilih menggunakan teknik atau metode evaluasi, karena hal ini akan membantu dosen memahami tujuan pembelajaran mana yang belum tercapai dan tujuan pembelajaran mana yang sudah tercapai. Baik dosen atau mahasiswa harus mengetahui perihal tersebut, agar mereka nantinya dapat bekerja sama untuk memperbaiki dan meningkatkan tujuan pembelajaran yang belum tercapai dan yang telah tercapai.

Dari berbagai uraian di atas, dapat disimpulkan bahwa penilaian diri adalah salah satu teknik penilaian yang dapat dilakukan oleh mahasiswa untuk membantu mereka dalam proses pengembangan keterampilan berpikir kritis yang relevan dengan keterampilan abad XXI. Selain dapat meningkatkan proses berpikir secara kritis, teknik penilaian tersebut memiliki berbagai macam kelebihan, salah satunya dapat membantu mahasiswa untuk menyadari kekuatan dan kelemahannya. Dalam konteks pembelajaran bahasa Jerman, teknik penilaian tersebut dapat diimplementasikan pada salah satu keterampilan berbahasa, khususnya keterampilan berbicara dalam bahasa Jerman.

Melalui tulisan ini dapat diketahui bahwa bahwa proses evaluasi hasil belajar mahasiswa tidak hanya dilihat dari sudut pandang dosen, tetapi juga dari sudut pandang mahasiswa itu sendiri. Oleh sebab itu, tujuan dari tulisan ini diharapkan dapat dijadikan solusi oleh dosen untuk menangani permasalahan penilaian dalam pembelajaran keterampilan berbicara bahasa Jerman.

\section{DAFTAR PUSTAKA}

Adliswil, Volker Rohr. 2018. Der Zusammenhang zwischen akkurate Selbsteinschätzung und Performanz im Wirtschaftlichen Kontext, Dissertation. Mannheim:Mannheim University

Alek. 2018. Linguistik Umum. Jakarta: Penerbil Erlangga.

Arikunto, Suharsimi. 2015. Dasar-Dasar Evaluasi Pendidikan Edisi 2. Jakarta: Bumi Aksara.

Baroya, Epi Hifmi. 2018. Strategi Pembelajaran Abad XXI. As-Salam Jurnal Ilmiah IlmuIlmu Keislaman. 1 (1): 101-115 


\section{PRASI JuRnal BAHASA, SENI, DAN PENGaJARANNYA \\ VOL. 15 | No. 02 | Desember 2020 \\ ISSN: Print 1693-6124 - Online 2614-1116}

Undiksha | DOI: http://dx.doi.org/10.23887/prasi.v15i02.29844 |https://ejournal.undiksha.ac.id/index.php/PRASI

BaŞak, Helin. 2019. Self-Assessment of Students' Speaking Skills (Tesis). Turkey: The Department of Englisch Language Teaching

Burg, Carel Van der. 2013. Werkzeugkiste Sprechen: Sprechen üben in grossen Gruppe. Mailand: Bildungskooperation Deutsch.

Darginaviciene, Irena. 2017. Self-Assessment of Language Skills and Evaluation of Performance in English for Specific Purposes Classrooms. Society Integration Education. III: 601-614

Fauziya, Diena San dan Suhara, Alfa Mitri. 2015. Evaluasi Pembelajaran melalui Penulisan Jurnal Reflektif Berbasis Penilaian Diri di PBS. Indonesia STKIP SILIWANGI. Jurnal Ilmiah UPT P2M STKIP Siliwangi. 2 (1): 46-52

Feri, Rose., Simadabrata, Marcellus., dan Jusuf, Anwar. 2015. Self-Assessment dalam Kegiatan Diskusi Problem-Based Learning Fakultas Kedokteran: Kajian Naratif. Jurnal Pendidikan Kedokteran Indonesia. 4 (3): 122-128

Harahap, Partomuan. 2017. Perbandingan Pengajaran Keterampilan Berbicara Bahasa Arab dan Bahasa Inggris di Sekolah Tinggi Agama Islam Negeri Curup. Jurnal Bahasa Arab. 1 (2): 154-178

Hasibuan, Ahmad Tarmizi dan Prastowo, Andi. 2019. Konsep Pendidikan Abad XXI: Kepemimpinan dan Pengembangan Sumber Daya Manusia SD/MI. Magistra. 10 (1): $26-50$

Jihad, Asep dan Haris, Abdul. 2012. Evaluasi Pembelajaran. Yogyakarta: Multi Presindo.

Lase, Delipiter. 2019. Pendidikan di Era Revolusi Industri 4.0. JCTES. 1 (1): 28-43

Lestari, Linda. 2016. Pengembangan Self Assessment Berbasis Website untuk Mengukur Ketercapaian Literasi Sains Siswa Pokok Bahasan Optik Kelas X (Skripsi). Semarang: Universitas Negeri Semarang

Lestuny, Carolina. 2020. Hubungana Pengetahuan Awal dan Diksi dengan Keterampilan Berbicara, Mahasiswa Program Studi Pendidikan Bahasa Jerman. Tahuri. 17 (1): $27-37$

Lindawati, Ni Putu dan Sengkey, Fenny. 2017. Peningkatan Keterampilan Berbicara Bahasa Inggris dengan Teknik Role Play pada Siswa Kelas X SMA Dwijendra Denpasar. Jurnal Manajemen Pelayanan Hotel Akademi Komunitas Manajemen Perhotelan Indonesia. 1 (1): 1-8

Majid, Abdul. 2015. Penilaian Otentik proses dan Hasil Belajar. Bandung: PT Remaja Rosdakarya Offset 
Mirici, Ismail Hakki. 2015. A Digital European Self-Assessment Tool for Student Teachers of Foreign Language: The Epost! TOJET: The Turkish Online Journal of Educational Technology. 14 (1): 1-10

Muhali. 2019. Pembelajaran Inovativ Abad Ke-21. Jurnal Penelitian dan Pengkajian Ilmu Pendidikan: e-Saintika. 3 (2): 25-50

Redhana, Wayan. 2019. Mengembangkan Keterampilan Abad ke 21 dalam Pembelajaran Kimia. Jurnal Inovasi Pendidikan Kimia. 13 (1): 2239-2253

Sajidan, rer.nat., Baedhowi., Totalia, Salman Alfarisy., dan Masykuri, Mohammad. 2018. Peningkatan Proses Pembelajaran dan Penilaian Pembelajaran Abad XXI dalam Meningkatkan Kualitas Pembelajaran SMK. Surakarta: Kementrian Pendidikan dan Kebudayaan.

Tenri, Andi., Asri, Wahyu Kurniati., dan Azizah, Laelah. 2017. Keefektifan Penggunaan Media Brettspiel dalam Keterampilan Berbicara Bahasa Jerman Siswa Kwlas X SMA Negeri 11 Makassar. Eralingua: Jurnal Pendidikan Bahasa Asing dan Sastra. 1 (1): $80-87$

Trim, North, Coste, dan Sheils. 2001. Gemeinsamer europäischer Referenzrahmen für Sprachen: lernen, lehren, beurteilen. Austria: Landesverlag.

Ulfiyani, Siti. 2016. Pemaksimalan Peran Guru dalam Pembelajaran Keterampilan Berbicara di Sekolah. Transformatika. 12 (2): 105-113

Wahyuni, Sri dan Ibrahim, Abd. Syukur. 2012. Assesmen Pembelajaran Bahasa. Bandung: PT Refika Aditama.

Widihastuti. 2015. Model Penilaian untuk Pembelajaran Abad XXI: Sebuah Kajian untuk Mempersiapkan SDM Kritis dan Kreatif. Prosiding Seminar Nasional, Jurusan Pendidikan Teknik Boga dan Busana Fakultas Teknik Universitas Negeri Yogyakarta. 10: 77-86

Wijayanti, Anita. 2017. Efektivitas Self Assessment dan Peer Assessment dalam Pembentukan Karakter Siswa. Realita. 15 (2): 1-14

Wijayanti, Enny dan Mundilarto. 2015. Pengembangan Instrumen Asesmen Diri dan Teman Sejawat Kompetensi Bidang Studi pada Mahasiswa. Jurnal Penelitian dan Evaluasi Pendidikan. 19 (2): 129-144

Winaryati, Eny. 2018. Penilaian Kompetensi Siswa Abad XXI. Seminar Nasional Edusaintek, FMIPA Universitas Muhamadiyah Semarang. 6-19 
Yamin, Moh. 2012. Panduan Manajemen Mutu Kurikulum Pendidikan. Jogjakarta: DIVA Press.

Zubaidah, Siti. 2016. Keterampilan Abad ke 21: Keterampilan yang Diajarkan Melalui Pembelajaran. Seminar Nasional Pendidikan Program Studi Pendidikan Biologi STKIP Persada Khatulistiwa Sintang, STKIP Persada Khatulistiwa Sintang. 1-17 